\title{
The Influence of School Library Utilization and Reading Interest on Student Achievement
}

\author{
Dheby Shintia \\ SD Negeri 176 Palembang \\ e-mail: dheby.shintia@yahoo.com \\ Yasir Arafat \\ Universitas PGRI Palembang \\ e-mail: yasirarafat@univpgri-palembang.ac.id \\ Andi Arif Setiawan \\ Universitas PGRI Palembang \\ e-mail: andiarifsetiawan@univpgri-palembang.ac.id \\ Article History: Received on 30 October 2021, Revised on 13 November 2021 \\ Published on 17 November 2021
}

\begin{abstract}
This study aimed at determining influence of using the school library and reading interest on student achievement fourth grade students of SD 04 OKU partially and simultaneously. This is a quantitative research with sampling using all class IV totaling 105 students. The variabels studied were the use of the school library $\left(\mathrm{X}_{1}\right)$, reading interest $\left(\mathrm{X}_{2}\right)$ and learning achievement (Y). Methods of data collection using a questionnaire. Data analysis using validity and reliability tests using the SPSS 22 for windows program. The results showed that there was an influence between the influences of the use of the school library on student achievement. This paper recommends to more focus on library and reading interest of students where school would have good students' achievement.
\end{abstract}

Keywords: Utilization of School Libraries, Reading Interest, Learning Achievement

\section{A. Introduction}

Education is a deliberate effort made by the government throughout life through various activities such as guidance, teaching, and training that take place at school and outside of school to prepare students to play appropriate roles in various living environments in the future (Maunah, 2009). Education is critical to ensuring the survival of the nation and state. This is due to the fact that education is a vehicle for improving and developing the quality of Human Resources. Realizing this goal will necessitate a lot of effort on the part of the community and the government. Development in the field of education is one of the efforts that can be made. Education that can develop students' potential so that those involved can face and solve life problems is important for future development (Al-Tabany, 2014).

Education implementation must consider not only the outcomes, but also the processes that occur during educational activities. The learning process is designed to help students develop their potential, which means that education must be student-centered in order for students' potential to be explored and developed. Furthermore, the educational process must eventually be capable of directing children toward religious spiritual strength, self-control, personality, intelligence, noble character, and skills required by themselves, society, nation, and state. 
According to this concept, education is a conscious and planned effort, so the educational process must be implemented correctly, and its orientation is to achieve the goals that have been set and planned. Education implementation must consider not only the outcomes, but also the processes that occur during educational activities. The learning process is designed to help students develop their potential, which means that education must be student-centered in order for students' potential to be explored and developed. Furthermore, the educational process must eventually be capable of directing children toward religious spiritual strength, self-control, personality, intelligence, noble character, and skills required by themselves, society, nation, and state.

One of the educational goals has been held, namely a set of educational outcomes attained by students. All educational activities, such as teaching, guidance, and training, are aimed at achieving educational objectives (Hamalik, 2013). According to Article 3 of Law No. 20 of 2003 Concerning the National Education System, the purpose of national education is to develop students' potential to become human beings who believe and fear God Almighty, have noble character, are healthy, knowledgeable, capable, creative, independent, and become democratic and responsible citizens.

To achieve educational success in schools, all school components must be supported, including principals, education staff, librarians, students, curriculum, teaching methods, and various supporting facilities for teaching and learning activities, all of whose positions influence and support one another in an effort to achieve success education. The availability of educational support facilities, specifically libraries, is the most important factor in achieving educational success. The presence of a library room in a school institution can provide more opportunities for students to be creative and develop themselves by increasing independent learning activities outside of the classroom, specifically by devoting a significant amount of time to reading as many books as possible in order to broaden their horizons of thinking, and this will, of course, have an impact on students improve their academic performance.

In the learning process, one of the most important learning resources is the library. According to Library Law No. 43 of 2007, a library is an institution that manages the collection of written works, printed works, and/or recorded works in a professional manner using a standard system to meet the needs of education, research, preservation, information, and recreation of students as the library's use. The school library is an essential component of education that cannot be separated from the existence of the school environment. Libraries can be viewed as information resource centers; these information resource centers promote lifelong learning. Perputakan provides educational information, educates its readers, and adds insight and knowledge to their lives (Suwarno, 2010).

According to Lasa (2007), a library is a room, part, or sub-section of a building or the building itself that is used to store books, usually in a specific arrangement and used by library members. The difference between students who do not use the library and students who come to use the library will reveal the long-term use of the library. Because the library is such an important tool in the teaching and learning process, it is regarded as the heart of the educational program. Libraries cover a wide range of knowledge and skills.

Furthermore, the library serves as a repository for national documentation, information, and cultural preservation. Students' activities in the teaching and learning process are no longer viewed as objects of learning, but rather as subjects of learning. Students must also be able to 
solve problems related to the process of learning, reading, researching, and engaging in positive and productive activities. To support all of this, school facilities such as school libraries, laboratories, and adequate teaching aids are required so that the learning process can be created in a harmonious and dynamic manner.

The organization of the school library is an attempt to keep and improve the efficiency and effectiveness of the teaching and learning process (Sinaga, 2009). As one of the educational facilities that supports student learning activities, the school library plays a critical role in promoting the achievement of educational goals in schools (Darmono, 2007). However, many students still do not use the library as a place to read and study. Even in a single school, library visitors are in short supply. Less active students can also have an impact on student achievement. The habituation of students to read has not been maximized by training students from giving subject assignments so that students are motivated to visit the school library, so it is feared that students will think reading is boring. So, in this case, the role of teachers and parents is required so that students no longer believe that reading is boring, but rather that reading is enjoyable.

Reading is a verbal or written exposure activity (reading is pronouncing words). Reading interest can be defined as a desire that arises from the heart without any coercion to understand and explain the contents of a word or sentence written in a book in order to gain extensive knowledge (Bafadal, 2014). Meanwhile, Djaali (2012) defines interest as "a sense of preference and a sense of interest in a thing or activity without anyone telling you." The acceptance of a relationship between oneself and something outside oneself is what interest is all about.

Reading is an important and fundamental habit that must be developed from a young age in order to improve the quality of education at all levels, including primary, secondary, and higher education (Hartono, 2016). In line with the rapid development of the era of technology, students' interest in visiting the library is decreasing; additionally, many students have not been able to utilize the library optimally due to a lack of awareness about the benefits that will be obtained. They will gain a lot of knowledge and broad insight by going through the books in the library. Through articles, novels, magazines, textbooks, comics, short stories, and other materials in the library, we can obtain information from various sciences and even information from all countries without having to travel to the country. In today's world of globalization and evolving technology, one of the most basic needs that must be met is information. However, few students are currently interested in reading, let alone visiting the library (Wakijo \& Sri, 2017).

Reading can also help you add to and improve your knowledge, broaden your perspectives, enrich your information, and stimulate the emergence of new ideas. Reading interest is related to learning outcomes because having a strong interest in reading increases our knowledge. Reading interest is defined in the Big Indonesian Dictionary as a strong emotional attachment to something, passion, or desire (Ministry of Education and Culture, 2003). Meanwhile, another definition of reading interest is a strong desire to read that is accompanied by efforts to read (Rahim, 2008). Thus, reading books is essential for children, adolescents, and parents alike. Because reading transcends time and space.

The implementation of formal education results in a high-quality education that is closely linked to student learning achievement. Learning achievement can be used to identify measurement standards that demonstrate students' ability to comprehend the learning process. 
A high level of learning achievement indicates learning success, whereas a low level of learning achievement indicates that the learning objectives achieved in learning activities were not implemented. The learning process is a process that is intentionally designed for the benefit of students and involves both the body and the soul; as a result, there is a change in the soul that affects behavior as a result of the learning process (Djamarah \& Bahri, 2008).

Achieving high learning achievement is difficult because learning success is heavily influenced by a variety of factors. Assessment of learning outcomes includes four (four) aspects: 1) aspects of knowledge and understanding of concepts, which are intended to find out how students can demonstrate their understanding; 2) aspects of thinking ability, which are intended to find out how students can think or show indicators that they can think; 3) skills aspects, which are intended to find out what students can do and indicate a change; and 4) behavioral aspects, which are intended to find out how student behavior shows positivity (Hidayat, 2013).

Several factors influence student achievement. Internal factors that influence learning outcomes include: a) physical factors, psychological factors (intelligence, attention, interests, talents, motives, perceptions, maturity, and readiness), and fatigue factors (consisting of physical exhaustion and fatigue, spiritual), and b) external factors, which include family and school factors (Slameto, 2010). The process of acquainting students with reading can be trained by assigning oriented tasks that encourage students to visit the library in search of reference materials. As a result, the teacher must be able to direct students' skills in terms of fostering student interest in reading so that students can become independent in seeking knowledge and adding insight during the teaching and learning process. It is hoped that as reading culture in educational institutions grows, learning achievement will improve.

Researchers discuss the factors that influence student achievement in this study, both external factors, such as the use of school libraries, and internal factors, such as students' reading interest. The use of libraries by students is one of the development priorities in the field of education because it is closely related to the learning process organized by educational institutions. State Elementary School 04 Ogan Komering Ulu is a Ministry of Educationaccredited educational institution located at Jalan Jend. A. Yani, Kemalaraja Village, East Baturaja District, Ogan Komering Ulu Regency. SD Negeri 04 OKU has a dynamic and professional management system in the implementation of education and teaching as a formal educational institution that organizes various activities. SD Negeri $04 \mathrm{OKU}$ is outfitted with facilities that aid in the success of education and learning. The available school facilities are quite complete to support the teaching and learning process, one of which is the presence of a special reading room or school library. The library will greatly aid teachers and students in their efforts to raise student achievement.

We also conducted initial observations at schools in January 2020, obtaining information that the library owned was quite good, there was an organizational structure consisting of the person in charge, the head of the library, and members. The library's reading room and book collection are more than adequate. The books they have range in genre from fiction to non-fiction, and the room is set up like a classroom with a table and chairs for reading. This is still insufficient to accommodate a large number of students who visit the library. The number of students who visit the library every day ranges between 10 and 20, but this information is not supported by guest books, so it can be assumed that the library's administration is not well documented. The library is managed by teachers who are seconded to manage the library; however, it is believed that more people are needed to provide library services. 
According to the findings of observations and the attendance list of library visitors, there are still some SD Negeri 04 OKU students who are eager to visit and use the library as a vehicle to broaden their knowledge horizon. This indicates that some SD Negeri 04 OKU students are interested in reading; however, it needs to be improved again so that student learning achievement improves. In accordance with the previous discussion, the role of library utilization for educational institutions in improving student achievement at SD Negeri 04 OKU, particularly class IV, is still enthusiastic about students visiting the library, so that we are interested in taking samples in class IV. Furthermore, the reading interest of fourth-grade students at SD Negeri $04 \mathrm{OKU}$ has a strong influence on their learning achievement. The greater the students' reading interest, the more knowledge they will gain and how well they will learn. Based on this description, the researcher feels compelled to conduct research on the impact of school library use and reading interest on student achievement.

\section{B. Methods}

SD Negeri 04 OKU, located at Jalan Jend. A. Yani, Kemalaraja Village, East Baturaja District, Ogan Komering Ulu Regency, conducted this research. This research is classified as quantitative research based on the objectives to be met, which is a research paradigm that views truth as something singular, objective, universal, and verifiable (Purwanto, 2010). The population in this study was 105 students, and all fourth grade students from SD Negeri 04 OKU were used as samples. This study used a variety of methods to collect data in the field, including observation, questionnaires, and documentation. The assumption test, which includes the data normality test, homogeneity test, and linearity test, was used in this study to analyze data. The hypothesis test consists of the product moment test, the f test, and the t test. When analyzing quantitative data, hypothesis testing is a technique that must be used. The researcher used the SPSS Version 20 application to help with the data analysis technique.

\section{Results and Discussion}

\section{The Effect of Library Utilization on Learning Achievement}

The variable utilization of school libraries on the learning achievement of fourth grade students of SD Negeri $4 \mathrm{OKU}$ is declared to have an effect with a significance of $0.033>0.005$, indicating that $\mathrm{Ho}$ is accepted. The use of school libraries has an effect on learning achievement.

Based on this research, it was discovered that library use is in the low category; library use is low because students rarely visit the school library; students prefer to use their break time to eat and play with their friends in class, canteen, or in the field. Reading is a way to get information, and to develop the habit of reading, what needs to be done is to motivate yourself to always want or access information, such as reading to the library, which is supported by Wiji's opinion, namely that reading interest can be aroused by quality and appealing reading material (Suwarno, 2011).

School libraries should be utilized because they provide numerous benefits to both students and teachers. According to Bafadal (2014) the library's function is educational, which means that the school library provides books, both fiction and non-fiction. The availability of these books can help students become acquainted with independent learning without teacher 
guidance, either individually or in groups. As a result, students should be able to use them independently as well as in groups. According to Zaelani and Margunani (2016), supporting research from this study, the use of the library is a center for student interaction with books, so the library is very influential in the learning process. The use of the school library has a very small effect on learning achievement because many other factors influence learning achievement, which are influenced by students' interest in learning and their surroundings.

According to Novriliam and Yunaldi (2012), the school library is used as a center for teaching and learning resources, which is in line with the opinion of Zaelani, R Margunani, M. If the school library plays an effective role in supporting the teaching and learning process, students will gain more knowledge, which will help them achieve their own learning goals. Libraries, according to Novriliam and Yunaldi (2012), play an important role in the learning process, so that learning objectives can be aided by the school library. Libraries have an impact on student achievement because they are an essential part of the educational system. Meanwhile, the school library, according to Riska (2019), is a significant source of learning. Libraries are very useful for students in terms of learning resources, in addition to being useful for teachers in terms of finding references. When students use the library as a learning resource, their academic performance improves. The theories and hypotheses put forward in this study, namely the influence of the school library on the learning achievement of fourth grade students at SD Negeri $04 \mathrm{OKU}$, are true.

\section{The Effect of Reading Interest on Academic Achievement}

According to the results of the above hypothesis, the variable of reading interest on the learning achievement of fourth grade students of SD Negeri 4 OKU has no effect with a significance of 0.0000 .005 , indicating that Ho is rejected. There is no significant effect because the increase in learning achievement is caused by factors other than a student's interest in reading, such as inadequate learning facilities, failure to complete assignments, and a lack of ability to manage study time.

According to Slameto's opinion, the fourth grade students of SD Negeri 04 OKU have a moderate level of interest in reading. Interest in reading is a sense of preference and a sense of interest in a thing or activity that can be expressed without anyone telling, an interest can be expressed through a statement that shows that students prefer one thing to another. Students who are interested in a particular subject tend to pay more attention to that subject (Slameto, 2010). Reading is the most important factor that can influence student achievement. Because students with a strong interest in reading will easily complete the assignments assigned by the teacher. He will also be extremely curious about knowledge.

This is consistent with the viewpoint of Bafadal (2014), who claims that reading is a factor that makes people smart, knowledgeable, and useful. As a result, in school, if students enjoy reading, it indicates that they are eager to expand their knowledge and learn new things. Expand your horizons and gain new insights. So that they will have high intelligence and civilization later in life and will be useful to themselves and others.

Students who enjoy reading and learning will almost certainly find it easier to achieve high grades or learning accomplishments than students who do not enjoy reading. Reading interest and desire do not come naturally to anyone, including children and school-age children, but 
they can be fostered and developed (Rosalin, 2008). Reading interest is also a person's enjoyment of reading because he believes it will benefit him (Ratnasari, 2016).

Kurniawati (2013) supports this research by stating that reading interest is more than just a desire to read but also what students read. Whether or not favorite reading has advantages, if what students read is textbooks and material presented by the teacher, it means that it has a significant impact on student achievement. However, most students do not see much benefit from reading, so it has no effect on their learning achievement. According to Widodo et al (2020), because students' interest in reading is closely related to their own motivation, it is necessary to create a learning environment that facilitates reading activities. Reading interest influences learning achievement when students' readings are related to academics or make references in completing study assignments. Meanwhile, reading is a student's skill, whereas interest is a student's desire. If students are not aware of the importance of reading, they will not read for pleasure. Readings must also be related to the subjects taught by the students or be references that aid in learning. Because there are many other factors that support increased learning achievement, such as repeating the lessons taught by the teacher and time management in learning, student interest in reading has little effect on student achievement. While the hypothesis in this study addressed whether or not library utilization had a significant influence on the learning achievement of fourth grade students at SD Negeri 04 OKU.

\section{The Effect of Library Utilization and Reading Interest on Learning Achievement}

According to the results of the above hypothesis, the two variables of school library utilization and reading interest on the learning achievement of fourth grade students of SD Negeri 4 OKU have no effect with a significance of 0.0000 .005 , indicating that Ho is rejected. There is no statistically significant relationship between the two variables X and Y. Not only does the use of the school library and reading interest affect learning achievement, but there are other factors that support the increase in learning achievement, such as learning motivation, less effective learning time management, and many others.

Learning achievement is the result of an educational assessment of students' learning development and progress. Achievement demonstrates the outcomes of school students' participation in activities. Mastery of the material taught by the teacher and the values contained in the curriculum can be used to assess student activities in schools. Furthermore, time and opportunity are factors that influence learning achievement. Because each person's time and opportunity are so different, it affects the differences in students' abilities. As a result, students who have a lot of time and opportunity to learn outperform those who have little time and opportunity to learn.

According to Puspitasari (2012), who supports this research, the use of school libraries for students is a very good thing because libraries are a source of knowledge. If students are uninterested in reading, they will be unmotivated to visit the library. The school library is not only a place for students to read, but it also has a variety of activities for students to participate in. Readings read by students have an effect on improving student achievement; in other words, readings related to textbooks can affect student achievement. Meanwhile, Astuti et al. (2020) claim that using school libraries in continuous learning can turn students who don't like to read into readers. Students can develop a stronger sense of curiosity by reading. Students' achievement is also greatly influenced by the readings they choose. While the hypothesis in this study answered that the variable X1 had an effect on the use of school libraries with 
significant learning achievement, Ho was accepted, while there was no significant effect on reading interest with learning achievement in the X2 variable, Ho was rejected. The effects of school library use and reading interest on fourth-grade students' learning achievement at SD Negeri 04 OKU.

\section{Conclusion}

The use of the school library has a significant positive effect (X1) on student achievement (Y). Reading interest (X2) has no significant positive effect on student achievement (Y). Reading interest (X1) and library utilization (X2) have no significant positive effect on student learning achievement (Y). According to the findings of this study, reading interest and library utilization do not have a significant impact on the learning achievement of fourth-grade students at SD Negeri 04 OKU.

\section{E. Acknowledgement}

We thank to SD Negeri 176 Palembang, Rector Universitas PGRI Palembang, Director of Graduate Program, the Education Management Study Program and friends who have supported us to do this project.

\section{References}

Al-Tabany, T. I. B. (2014). Mendesain Model Pembelajaran Inovatif, Progresif, dan Konstektual [Designing Innovative, Progressive, and Contextual Learning Models]. Jakarta: Prenada Media.

Astuti, F. Y., Faishol, R., \& Trianingsih, R. (2020). Pengaruh Pemanfaatan Perpustakaan Sekolah Terhadap Minat Baca Pada Mata Pelajaran SKI Kelas XI Agama Di MAN 2 Banyuwangi [The Effect of School Library Utilization on Reading Interest in SKI Class XI Religion Subjects at MAN 2 Banyuwangi]. Ar-Risalah: Media Keislaman, Pendidikan dan Hukum Islam, 18(1), 054-082.

Bafadal, I. (2014). Pengelolaan Perpustakaan Sekolah [School Library Management]. Jakarta: Bumi Aksara

Darmono. (2007). Perpustakaan Sekolah Pendekatan Aspek Manajemen dan Tata Kerja [School Library Management and Work Procedure Approach]. Jakarta: Grasindo.

Djamarah, \& Bahri, S. (2008). Psikologi Belajar [Learning Psychology]. Jakarta: Rineka Cipta.

Departemen Pendidikan dan Kebudayan. (2003). Undang-Undang no 20 Tahun 2003 tentang Sistem Pendidikan Nasional [Law No. 20 of 2003 concerning the National Education System]. Jakarta: Sinar Grafika.

Djaali. (2012). Psikologi Pendidikan [Educational Psychology]. Jakarta: Bumi Aksara

Hamalik, O. (2013). Kurikulum dan Pembelajaran [Curriculum and Learning]. Jakarta: Bumi Aksara. 
Hartono. (2016). Manajemen Perpustakaan Sekolah [School Library Management]. Yogyakarta: Ar-Ruzz Media.

Hidayat, S. (2013). Teori dan Prinsip Pendidikan [Educational Theories and Principles]. Tangerang: Pustaka Mandiri.

Kurniawati, A. (2013). Hubungan Antara Prestasi Belajar IPS, Minat Baca Status Sosial Ekonomi dan Pemanfaatan Jejaring Sosial Dikalangan Siswa SMP Kecamatan Semin Kabupaten Gunung Kidul [The Relationship Between Social Studies Learning Achievement, Interest in Reading Socio-Economic Status and Utilization of Social Networks Among Junior High School Students, Semin District, Gunung Kidul Regency].

Lasa, H. (2007). Manajemen Perpustakaan [Library Management]. Yogyakarta: Pinus Book Publisher.

Maunah, B. (2009). Landasan Pendidikan [Educational Foundation]. Yogyakarta: Teras.

Novriliam, R., \& Yunaldi, Y. (2012). Pemanfaatan Perpustakaan Sekolah Sebagai Pusat Sumber Belajar di Sekolah Dasar Negeri 23 Painan Utara [Utilization of the School Library as a Learning Resource Center at 23 North Painan Elementary School]. Ilmu Informasi Perpustakaan dan Kearsipan, 1(1), 141-150.

Purwanto, N. (2010). Prinsip-Prinsip dan Teknik Evaluasi Pengajaran [Teaching Evaluation Principles and Techniques]. Bandung: Remaja Rosdakarya.

Puspitasari, K. (2012). Pengaruh Pemanfaatan Perpustakaan Sekolah Dan Minat Baca Terhadap Hasil Belajar Siswa Kelas XI IPS Pada Mata Pelajaran Ekonomi di SMA Negeri 4 Malang [The Effect of School Library Utilization and Reading Interest on the Learning Outcomes of Class XI Social Sciences Students in Economics Subjects at SMA Negeri 4 Malang]. Skripsi Jurusan Ekonomi Pembangunan-Fakultas Ekonomi UM.

Rahim, F. (2008). Pengajaran Membaca di Sekolah Dasar [Teaching Reading in Elementary School]. Jakarta: Bumi Aksara.

Riska, A. (2019). Pemanfaatan Perpustakaan Sekolah Sebagai Sumber Belajar Siswa SD Inpres 12/79 Biru II Kecamatan Tanete Riattang Kabupaten Bone [Utilization of School Libraries as Learning Resources for Students of SD Inpres 12/79 Biru II, Tanete Riattang District, Bone Regency]. JIKAP PGSD: Jurnal Ilmiah Ilmu Kependidikan, 3(2), 165-175.

Rosalin, E. (2008). Pemanfaatan Perpustakaan Dan Sumber Informasi [Utilization of Libraries and Information Resources]. Bandung: Rineka Cipta.

Slameto. (2010). Belajar dan Faktor-Faktor yang Mempengaruhinya [Learning and the Factors That Affect It]. Jakarta: Rineka Cipta. 
Volume 2 (2) 2021

E-ISSN: 2723-6919 P-ISSN:2746-0827

Sinaga, D. (2011). Mengelola Perpustakaan Sekolah [Managing School Libraries]. Bandung: Bejana.

Suwarno, W. (2010). Ilmu Perpustakaan \& Kode Etik Pustakawan [Library Science \& Librarian Code of Ethics]. Malang: IKIP Malang.

Wakijo \& Novita, S. (2017). Pengaruh Pemanfaatan Perpustakaan Sekolah dan Minat Baca Siswa terhadap Hasil Belajar IPS Terpadu Siswa Kelas VII Semester Genap SMP Negeri 2 Metro Tahun Ajaran 2016/2017 [The Effect of School Library Utilization and Students' Reading Interest on Integrated Social Studies Learning Outcomes for Class VII Even Semester Students of SMP Negeri 2 Metro Academic Year 2016/2017]. Lampung: Pendidikan Ekonomi FKIP Universitas Metro.

Widodo, A., Husniati, H., Indraswati, D., Rahmatih, A. N., \& Novitasari, S. (2020). Prestasi Belajar Mahasiswa PGSD Pada Mata Kuliah Pengantar Pendidikan Ditinjau Dari Segi Minat Baca [PGSD Student Learning Achievements in Introductory Education Courses in Terms of Reading Interest]. Jurnal Bidang Pendidikan Dasar, 4(1), 38-46.

Zaelani, R., \& Margunani, M. (2016). Peran Minat Belajar Sebagai Intervening Dalam Pengaruh Lingkungan Keluarga dan Pemanfaatan, \& Perpustakaan Sekolah Terhadap Prestasi Belajar Akuntansi [The Role of Interest in Learning as an Intervening in the Influence of the Family Environment and Utilization, \& School Libraries on Accounting Learning Achievement]. Economic Education Analysis Journal, 5(2), 532532. 